\title{
Theoretical understanding between competitiveness and productivity: firm level
}

\section{Comprensión teórica entre competitividad y productividad: Ámbito de la empresa}

\author{
Aline Dresch ${ }^{1}$, Dalila C. Collatto ${ }^{2} \S$, Daniel P. Lacerda ${ }^{1}$ \\ ${ }^{1}$ Post-Graduate Program in Production Engineering - PPGEP/UFSC, Research Group \\ on Modeling for Learning - GMAP | UNISINOS, São Leopoldo, Brasil \\ ${ }^{2}$ Federal Institute Sul-rio-grandense, IFSUL, Sapucaia do Sul, Brasil \\ aldresch@unisinos.br,dcollatto@sapucaia.ifsul.edu.br,dlacerda@unisinos.br
}

(Recibido: 30 de octubre de 2017 - Aceptado: 28 de abril de 2018)

\begin{abstract}
Resumen
El objetivo de este artículo es contribuir para la comprensión del concepto de competitividad en el nivel de empresa y su relación con la productividad. Se conduce una revisión sistemática de la literatura pertinente al tema y, posteriormente fue estructurado un análisis de los elementos encontrados en la literatura por medio del pensamiento sistémico. El pensamiento sistémico permite identificar las relaciones de causa y efecto entre los elementos que accionan la competitividad, evidenciando las convergencias y divergencias entre esos elementos. Se concluyó que la productividad se destacó entre los demás elementos confirmando su importancia en la determinación de la competitividad.
\end{abstract}

Palabras clave: Competitividad, Empresa, Pensamiento sistémico, Productividad.

\begin{abstract}
The objective of this article is to contribute to the understanding of the concept of competitiveness at firm level and its relation to productivity. To support the objective of this work, a systematic review of the literature was conducted and was subsequently structured an analysis of the elements found in the literature through systems thinking. Systems thinking enables to identify the cause and effect between the elements of competitiveness, highlighting the convergence and divergence between these elements. It was concluded that productivity stood out among the other elements confirming its importance in determining firm competitiveness. Limitations of this study consists on the theoretical nature, there is the need for an empirical study to verify the practical effect of productivity on competitiveness at the firm level.
\end{abstract}

Keywords: competitiveness, productivity, firm, company, systemic thinking. 


\section{Introduction}

In the year of 2015, Brazil lost 18 positions in the World Economic Forum ranking, that annually assesses the competitiveness of countries ${ }^{(1)}$. However, other emerging countries showed economic growth and increases in competitiveness in the same period ${ }^{(2)}$. This information, presented as an example, highlights the relevance of understanding the dimensions that involve competitiveness. Thus, it is necessary an articulation between the private sector of the country and public agencies to reverse this trend, expanding the capacity of the industry to compete in the international market ${ }^{(2)}$.

In this scenario the competitiveness is among factors influencing companies' position and makes them structured to better compete in the market. A competitive company can market products and services efficiently and effectively, with appropriate prices and quality for customers ${ }^{(4)}$. Therefore, the competitiveness at firm level can be perceived as a sustainable position of the company to meet the forces of competition in a given business sector, in order to overcome its rivals in terms of long-term profitability ${ }^{(3)}$.

Thus, competitiveness, from the point of view of competitive advantage, is treated as the advantage of proactively perceiving market trends ahead of competitors and adjusting supply according to this anticipation ${ }^{(4)}$. The competitive advantage can be based on different functional areas within the organization, as examples that can generate the competitive advantages: to attend smaller cycles of product deliveries; have product with quality and reliability; fulfill the promise of delivery; be able to quickly produce new products, and have the flexibility to adjust volume changes and lower costs ${ }^{(5)}$. With these practices, although they seem easy to apply, they require a lot of commitment and competence ${ }^{(5)}$.

One of the ways to increase competitiveness is to act in the increase of productivity. It should be noted that competitiveness and productivity are complementary concepts, and for competitiveness it is necessary solid bases of productivity ${ }^{(6)}$. Besides that, the increase in productivity is, notoriously, a condition for the growth of the economy ${ }^{(7)}$.

The productivity corresponds to a measure to verify how well the resources to produce a certain result are employed ${ }^{(8)}$. Inputs correspond to resources used in the production process as raw material, equipment, labor and other factors of production, while outputs correspond to the results of the production process, obtained through the use of these resources ${ }^{(8)}$.

Just as productivity impacts the competitiveness of a country or the sector, it is also a fundamental element for increasing the competitiveness of the companies themselves. Competition, in general, influences the business environment, both in the definition of strategies, objectives and goals of the organization, as well as in the structuring of resources necessary to execute internal processes in a dynamic and efficient manner. Thus, the competitive company is one that has the ability to deliver products and services, effectively, with prices and quality appropriate to its consumer ${ }^{(9)}$.

Thus, companies continually seek ways to adapt to economic, social, political, technological and structural changes, that is, to the environmental changes. As a consequence of these changes, organizations face situations of uncertainty and are exposed to a series of threats and opportunities, which influence the choice of strategies, the definition of objectives and the decision-making process ${ }^{(10)}$.

Given this context, the aim of this paper is to contribute to understand the concept of com-petitiveness at the company level and its relation with productivity. In addition to that, the main elements that constitute the competitiveness concept will be cataloged, in the level of the company. This objective was mainly materialized through a systematic literature review on the subject of competitiveness and productivity, giving this work an eminently theoretical feature. To support the understanding of the interrelations between the drivers of competitiveness, among them productivity, the systemic thinking was used. 
The justification for carrying out this study, under the academic dimension, is the shortage of addressing competitiveness and its driving elements at the level of the company. In this sense, the systematic literature review allowed us to identify that the concept of competitiveness and productivity are treated in an isolated manner and without the perception of the connection between them ${ }^{(6)}$.

From the managerial point of view, the importance of this paper is to generate specialized knowledge regarding the reciprocal influences of the elements of competitiveness impulse, revealed by the systemic thinking language. Therefore, the application of systemic thinking is justified by broadening the perception of the relationship between competitiveness and its driving elements, giving the basis for determining actions in the conduct of business enterprises.

\section{Competitiveness}

Competitiveness can be conceptualized under different perspectives or dimensions. Competitiveness can be measured according to their level of analysis: country, sector, company ${ }^{(11-13)}$. The competitiveness of the company depends of the connection between the competitiveness in country and sector level, as well as its own level of competitiveness. The first level, country competitiveness, includes variables such as macroeconomic stability, access to international markets or the complexity of regulation for the business sector; the second level, sectoral competitiveness, refers to the regional infrastructure; and the third level explains the competitiveness of the company, in what must be turned to the internal analysis of the organization ${ }^{(6)}$.

A competitive company is the one that has the ability to generate profit and have significant market share ${ }^{(14)}$. However, to be considered competitive, the company must use its resources and its capacity to produce the right products and services, with quality, an appropriate price and in the correct number ${ }^{(13)}$, so it can commercialize, effectively, its products to the consumer market ${ }^{(15)}$.
In order to be competitive, any company must offer products and services that customers are willing to pay ${ }^{(12)}$. In the long term, in a free trade system, competitiveness is measured by the ability of the company to continue the business and protect its investments, generating return on investments and guaranteeing future employment ${ }^{(9,12)}$.

The immediate and future capacity to generate opportunities for entrepreneurs is one of the aspects of competitiveness ${ }^{(16)}$, and also highlights that the company must project, produce and market products around the world, whose price and qualities form a more attractive package than the competition. Siudek and Zawojska (2014) ${ }^{(9)}$, affirm that the competitiveness of a company depends on the combination of tangible and intangible assets. These assets include human resources, material inputs, segment infrastructure, technology, reputation, trademarks and processes within the organization ${ }^{(9)}$. These elements, combined, offer competitive advantages and can be referred to as sources of competitiveness ${ }^{(9)}$.

To better understand the company competitiveness, it is essential to determine its endogenous and dynamic characteristics, since both terms focus on increasing productivity and the development of technology, reducing costs or depreciation ${ }^{(17)}$. In the company level, the increase of productivity reflects in the improvement of competitiveness, therefore productivity directly impacts competitiveness ${ }^{(18)}$.

There are more radical visions that emphasize that if competitiveness has any meaning, it is just another way of expressing productivity ${ }^{(19)}$. The competitiveness of a country, sector and company is decided by its productivity, so productivity is considered one of the main determinants of competitiveness and, even, equated to this ${ }^{(9)}$.

However, although productivity is a key factor for the competitiveness of a company, other elements also concur for competitiveness. In this way, business competitiveness depends, in addition to productivity, on profitability, on the competitive position, on participation in the internal and exter- 
nal market, on its inter-company relations, on the sector and on regional infrastructure as a whole ${ }^{(6)}$.

In fact, productivity is an element that significantly impacts competitiveness at the company level, being considered one of the measures of competitiveness performance. In the following section, we present the main productivity concepts in company level.

\subsection{Productivity}

Productivity is the only relevant measure of competitiveness ${ }^{(3)}$. Thus, the increase in productivity implies the improvement of competitiveness, but Buckley et al. (1988) ${ }^{(15)}$ points out that productivity is one of the elements of competitiveness.

The productivity parameter serves as the equivalent for competitiveness and can be applied at the country, sector, and company level. In the field of business, productivity establishes coherence between the organizational goals and aspirations of society through the input and output relationships ${ }^{(20)}$. Productivity is the result of interactions of organizational management systems with external environment factors and, fundamentally, this concepts aim to accelerate actions in the sense of improving performance in multiple dimensions ${ }^{(20)}$.

Productivity can be understood as the ability to transform the inputs used in the production process into products ${ }^{(21)}$. This ability can be measured by the efficiency of production ${ }^{(22,23)}$, which is a comparative measure that represents the use of resources, that is, what was produced with the use of certain resources compared to what could have been produced with these same resources ${ }^{(22)}$. We can say that efficiency can be described as an optimal location of resources to achieve the desired ends ${ }^{(24)}$.

Productivity is commonly defined as the relationship between production and resources, that is, compares what was produced with the amount of resources used ${ }^{(25)}$. Resource signify all the means that are used to generate products, whether services or goods, among resources: labor, materials, machines and supplies (energy, water, other complementary materials) ${ }^{(25)}$.
The productivity concept is related to obtaining the maximum results with the minimum of efforts, or resources used, so you can define productivity, also, as a metric, an indicator that allows to guide, as well as manage resources better. It is, therefore, a measure of effectiveness, or of how productive means are used, to do things the right way ${ }^{(25)}$.

To monitor the behavior of the relationship between production and resources, it is necessary to analyze the performance of productivity. The productivity analysis is a technique used to evaluate performance and contributes to the search for improvement alternatives ${ }^{(20)}$. The efficient frontier can be constructed to characterize the degree of efficiency of production processes that use inputs to generate outputs, considering the same input source, inefficiency is indicated by the lower levels of the output system ${ }^{(20)}$.

In the economy, productivity is the ration of what is produced and what is required for that production (22), this is measured by the comparison of inputs and outputs of resources ${ }^{(26)}$. Normally that ratio is in the form of an average, which expresses the total output of some category of goods, divided by the total of inputs. In principle, any input can be used as a denominator of productivity ${ }^{(22)}$.

Productivity metrics refer, essentially, to measures of inputs and outputs of a single, or combination of inputs, in order to grant comparisons over time, between plants or in relation to some model ${ }^{(27)}$. The choice of which form to use depends on the purpose of the measurement of productivity and the availability of the data ${ }^{(28)}$.

In this sense, productivity measures can be divided between partial and total ${ }^{(28,29)}$. Partial productivity measures the relationship between inputs and outputs, considering as outputs those related to the operation itself, such as labor, energy consumption, among others. I.e.: 110 production / man, 40 production / hour. The most common partial measure is labor productivity, which often measures production per hour or per employee. The most common partial measure is labor productivity, which often measures production per 
hour or per employee ${ }^{(29)}$. Total productivity, in turn, measures the proportion of total outputs by total inputs, considering capital ${ }^{(28,30)}$. When dealing with complex projects, the availability of industrial machines must be a constituent of equations in the rate of productivity. Manufacturing systems often use the term physical productivity, which is the ratio between the number of products manufactured in time ${ }^{(31)}$. This term includes technical, technological and managerial information that can be used for subsequent evaluation of the efficiency of the production system. This term does not take into account the labor costs of the manufacturing process ${ }^{(31)}$, then it is a partial measure of productivity.

Therefore, measuring productivity is reflected in changes in production efficiency ${ }^{(22,28)}$ and can contribute like this, so that companies are more lucrative ${ }^{(30)}$. In fact, there are different ways to measure productivity, in common they want to measure performance, allied to the interest of modifying that performance, some reasons why productivity is measured ${ }^{(32)}$ : (i) measure the performance of individuals / departments of a Company; (ii) generate an index of production capacity of wealth of industries or economies; (iii) the influence of productivity on prices, both for companies and for reasons of public order; (iv) measure the performance of a company or industry over time; (v) performance comparisons between companies in an industry, sectors and between countries; (vi) compare the performance of companies / industries under alternative public policy regimes, for example, regulation and / or government ownership.

So, the measures of the productivity of a company are related to the productive processes, being this way, the failures in the production, when they are corrected in time, avoid damages in the productivity. Therefore, increasing the productivity of the company requires effort to identify and analyze inefficient resources, to act in the sense of cutting unnecessary expenditures, and increase the economic and financial result of the Company ${ }^{(24)}$. In highly productive organizations it is possible to conclude that there is a correlation between productivity and competi- tive advantages, and among their strengths is the high quality in the process, quality of supplies, reduced stock, speed in manufacturing, flexibility to change products ${ }^{(33)}$. Productivity measures indicate the interaction between products or services produced and capital and labor resources used ${ }^{(29)}$.

It should be noted that in this work, the effort was directed towards the understanding of the interrelationships between competitiveness and productivity. Thus, the approach used for the perception of interrelations was systemic thinking.

\subsection{Systemic Thinking}

Systemic Thinking can be defined as a way of perceiving reality ${ }^{(34,35)}$. In the science of the 20th century, the holistic perspective becomes known as systemic and the way of understanding the relationships between the different elements forming a system becomes known as Systemic Thinking ${ }^{(36)}$. Systemic Thinking can be defined as a subject, that helps in the development of studies that unite theory and practice, allowing to develop the vision of the whole, and the interrelationships instead of things, in a dynamic way ${ }^{(36)}$.

Systemic thinking modifies the emphasis on approaching systems ${ }^{\left({ }^{34}\right)}$. While the mechanistic approach seeks to understand the systems by the parties, following a linear logic of absolute and quantitative truths, in the systemic approach, the emphasis is on the whole, following a circular logic that identifies links ${ }^{(34)}$.

Thus, the perception of the importance of an element from the whole in which it is inserted is adherent to the precepts of Systemic Thinking ${ }^{(34)}$. Therefore, the core of Systemic Thinking is the change of mentality, in the understanding of the interrelations instead of linear chains of cause and effect ${ }^{(36)}$.

One of the main working models of systemic thinking is focused on the levels of perception of reality ${ }^{(34)}$. Thus, one way of applying the Systemic Thinking was presented by Senge $(1990)^{(37)}$. According to this model, reality is structured in layers ${ }^{(36)}$ : 
Events: they occur and are perceived by the people involved, in this way they question the perceptions of events.

Behavioral patterns: events are evidence of variations in deeper behavioral patterns. In this layer, long-term trends are analyzed, and analysis graphs are used to understand past behavior and look for evidence that can predict their future or desired behavior.

Systemic structure (or systemic map): at this le-vel, the understanding of reality takes place, by identifying the causes of behavioral patterns, seeking to understand how the variables influence each other in relation to cause and effect. Systemic maps are the basis for system design.

Mental models: it is necessary to identify how mental models generate or influence systemic structures, so that they are susceptible to understanding and modification.

The systemic language is an instrument used to put in practice the systemic ideas ${ }^{(34)}$. The systemic structure, in turn, provides reflection based on the whole, on the relationships of the objects and the search for the understanding of reality more as networks, than as hierarchies ${ }^{(34)}$.

In this sense, (38) attribute the term systemic competitiveness to the analysis of the factors that determine the interrelationships of competitiveness. The competitiveness of a company is based on the standard of the organizational structure of society as a whole, presenting parameters of competitive relevance at all levels of the system and the interaction between them is what generates competitive advantages ${ }^{(38)}$.

In order to analyze the results, they point out that industrial competitiveness is the result of the complex and dynamic interaction between four economic and social levels of a national system: i) micro level of companies that seek simultaneously efficiency, quality, flexibility and speed of reaction, many of them articulated in networks of mutual collaboration; ii) the meso level, corresponding to the State and social actors, that develop specific support policies, encourage the formation of structures and articulate learning processes at the level of society; iii) the macro level, which puts pressure on companies for performance demands; and iv) target level, structured with solid basic standards of legal, political and economic organization, sufficient social organization capacity and integration and capacity of actors for strategic integration ${ }^{(38)}$.

Applying the Systemic Thinking can also help in understanding the interrelationships of each level of competitiveness. In this sense, the effort of this research is centered application of the concepts of systemic thinking at the micro, enterprise level, as presented in the methodology item.

\section{Methodology}

In order to meet the objective of the study, a systematic literature review was carried out, based on the procedures proposed by Morandi and Camargo $(2015)^{(39)}$, presented in the figure 1 . The motivation for this study is linked to the need of the private sector and public agencies to reverse the declining trend of the country's competitiveness, based on the increase in productivity in companies. For this, it is necessary to understand the determinants of competitiveness, including productivity. It also seeks to identify indicators for measuring competitiveness and productivity in the companies.

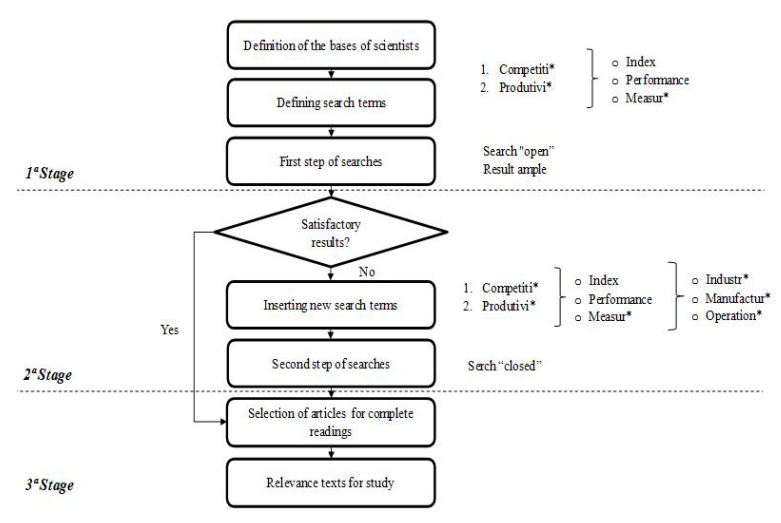

Figure 1. Stages of the Systematic Literature Review

The search strategy was based on international and national papers collected from the database EBSCO Host, Scopus, Scielo Br, which are part of the 
main databases for studies in the management area ${ }^{(39)}$. There was no temporary cut for the investigation and the search stage was sequenced in two main phases. Figure 1 shows the three stages of the systematic literature review, search for enforceability and codification, for later evaluation of the quality of the study and synthesis of the results.

In the first phase of searches, called open search, were selected the radicals of the words competitiveness and productivity - Competitivi* and Produtivi* - added to the terms measur*, performance, index in scientific journals. The result generated was an expressive quantity of articles that did not satisfy the needs of the study in terms of adherence to the objective of the study.

In the second phase of searches, were defined new keywords with the aim of restricting the quantitative of publications and aligning the result with the objective of the study. For this closed search, the radicals of the words competitiveness and productivity were used, the terms measur*, performance, index; allies to industry context terms - industr*, manufactur* and operation*.

The inspectional reading was carried out by three different researchers and of each of the studies found, 325 relevant studies were selected to answer the question of revision. For the selection of these studies, the established requirement was to contemplate, at least, one of the following criteria: (i) present the concept of competitiveness and productivity; (ii) link at least two indicators of competitiveness and productivity measurement in the field of companies. By not presenting any of the two established requirements, the article was excluded from the analysis. Studies focused only on competitiveness of the country and the sector were also excluded from the analysis, since the objective of this study is competitiveness and productivity at the company level. Papers were also excluded from the analysis duplicate reports of the same study (when several reports of a study exist in different journals the most complete version of the study was included in the review).

The inspection reading process, in which the titles and summaries of the studies are read, help in verifying the relevance of the texts for this study ${ }^{(39)}$. After the selection of the relevant texts, they were analyzed in depth. Table 1 shows the synthesis of the results of the study in the databases and Appendix 1 presents information on selected articles (54 articles).

Table 1. Results Database Search

\begin{tabular}{cccc}
\hline Terms & $1^{\mathrm{a}}$ stage & $2^{\mathrm{a}}$ stage & $3^{\mathrm{a}}$ stage \\
\hline Competitive & 4.294 & 146 & 27 \\
Productive & 5.586 & 179 & 31 \\
Total & 9.880 & 325 & 58 \\
\hline
\end{tabular}

After reading the relevant texts, on the aspects that make up the competitiveness, surveys were made and linked to the author of the study. For this, a spreadsheet was used to compute the number of competitiveness elements cited in each paper.

Finally, the researchers sought to identify the interrelationships between aspects that drive competitiveness through the construction of the systemic map (or systemic structure), that covers the central elements of competitiveness, considering the articles analyzed in the systematic literature review. After, they present to compensate the cause and effect relationships existing between elements of competitiveness at firm level and its applying the systemic thinking followed the four structured in layers' steps pointed out by Senge $(1990)^{(34)}$, presented in item 2.2.

\section{Aspects that drive competitiveness at company level}

The factors that make up and boost competitiveness are often used as metrics to measure the companies' competitiveness. There is a diversity of ways to monitor competitiveness and, consequently, the performance of the company in that aspect ${ }^{(15)}$. In this way, there is no synthetic measure or a single index that reveals the performance of competitiveness ${ }^{(12)}$. In this sense, there are different understandings of what compose the competitiveness ${ }^{(15)}$. For some authors, competitiveness can be understood as the ability to execute 
well or, as well as the generation and maintenance of competitive advantages ${ }^{(15)}$.

Based on the hypothesis that there is no single way to monitor and evaluate the performance of competitiveness at the company level, we sought, in the literature, to identify which are the central aspects that interfere in the competitiveness of a company. Table 2 shows the authors, year of publication, the aspects that drive competitiveness and its frequency among the analyzed studies.

Table 2. Aspects that drive competitiveness

\begin{tabular}{|c|c|c|c|c|c|c|c|c|c|c|}
\hline Elements & 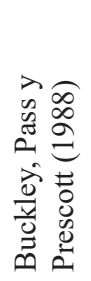 & 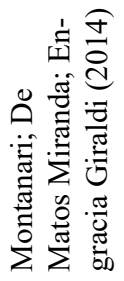 & 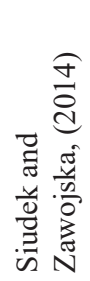 & 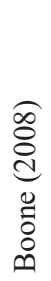 & 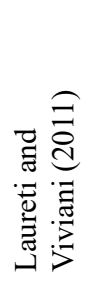 & 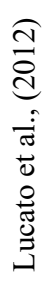 & 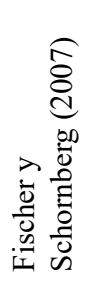 & 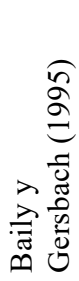 & 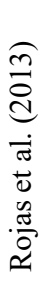 & 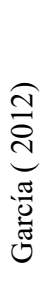 \\
\hline Cost and price & $\mathrm{x}$ & & $\mathrm{x}$ & & & $\mathrm{x}$ & & & & \\
\hline Efficiency & & & $\mathrm{x}$ & $\mathrm{x}$ & & & & & & $\mathrm{x}$ \\
\hline $\begin{array}{l}\mathrm{R} \& \mathrm{D} \text { and Innovation } \\
\text { investment }\end{array}$ & $\mathrm{x}$ & & $\mathrm{x}$ & & & & & $\mathrm{x}$ & $\mathrm{x}$ & \\
\hline Profit & $\mathrm{x}$ & $\mathrm{x}$ & $\mathrm{x}$ & $\mathrm{x}$ & & & $\mathrm{x}$ & & & \\
\hline Market share & $\mathrm{x}$ & $\mathrm{x}$ & $\mathrm{x}$ & & & $\mathrm{x}$ & & & & $\mathrm{x}$ \\
\hline Marketing & $\mathrm{x}$ & & $\mathrm{x}$ & & & & & & & $\mathrm{x}$ \\
\hline Financial measures & & & & & $\mathrm{x}$ & $\mathrm{x}$ & $\mathrm{x}$ & & & $\mathrm{x}$ \\
\hline Operations & & & & & & $\mathrm{x}$ & & $\mathrm{x}$ & & $\mathrm{x}$ \\
\hline Productivity & $\mathrm{x}$ & & $\mathrm{x}$ & & $\mathrm{x}$ & $\mathrm{x}$ & $\mathrm{x}$ & $\mathrm{x}$ & & $\mathrm{x}$ \\
\hline Human Resources & & & $\mathrm{x}$ & & & & & & & $\mathrm{x}$ \\
\hline Customer satisfaction & $\mathrm{x}$ & & $\mathrm{x}$ & & & $\mathrm{x}$ & & & & \\
\hline Technology & $\mathrm{x}$ & & $\mathrm{x}$ & & & & & & & $\mathrm{x}$ \\
\hline
\end{tabular}

Analyzing the results summarized in Table 2, it is identified that, in studies that address aspects that compose and can measure competitiveness, the main elements that are addressed by the authors are: (i) productivity; (ii) profit; (iii) market share; (iv) R\&D and Innovation Investment. The productivity element was the one that presented the highest frequency of citation in the studies analyzed, and is the focus of investigation of those papers. Based on this result we seek to understand, more deeply, the authors' perception of productivity.

The different vision and aspects presented in terms of productivity are analyzed together with the other elements of competitiveness and allow us to deduce that productivity is the key element of competitiveness. This analysis was possible through the construction of the systemic map (or systemic structure) that covers the central elements of competitiveness, considering the articles analyzed in the systematic literature review. Figure 2 presents the systemic map evidencing the variables and the cause and effect relationships between them. It should be noted that intermediate variables, besides those identified in the literature, were inserted to ensure the real meaning of systemic links, as suggested, seeking to ensure logical consistency on systemic map. 


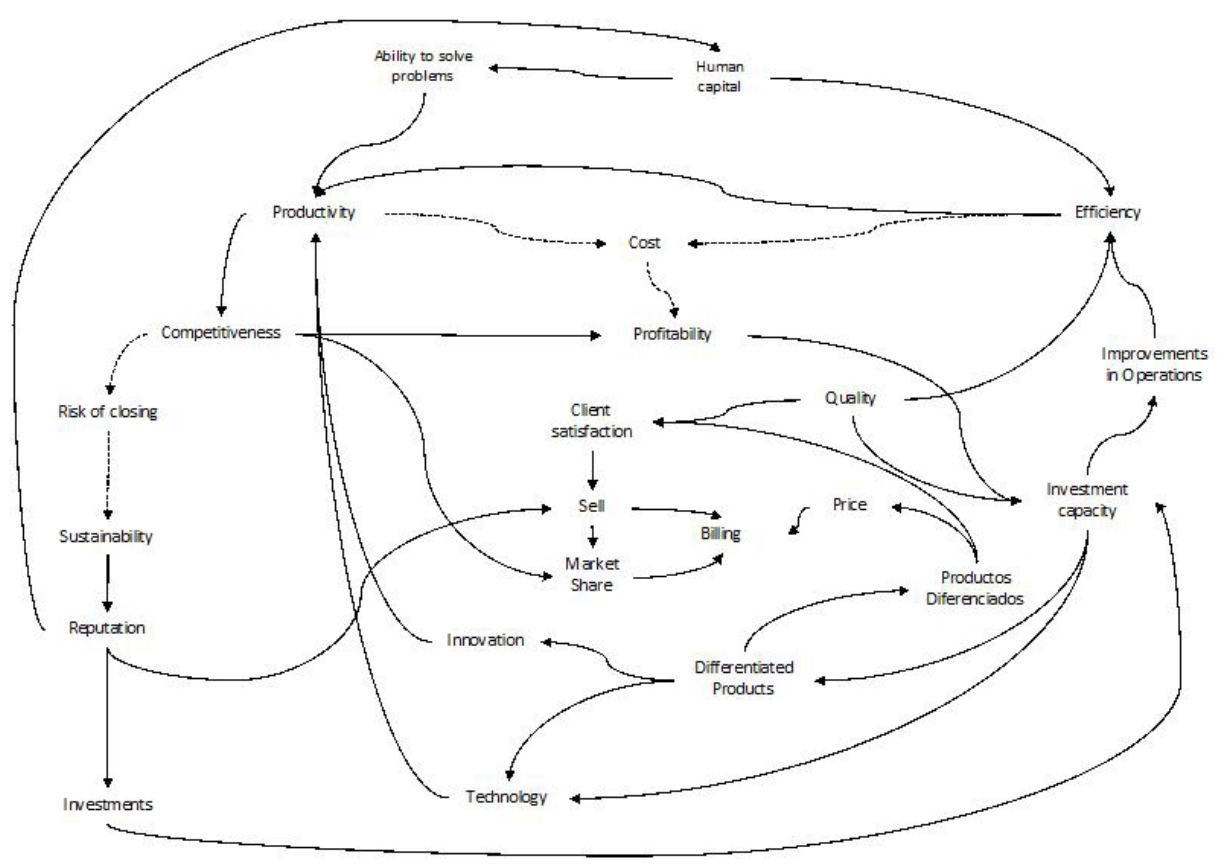

Figure 2. Systemic map

This systemic map allows to visualize the competitiveness related to its driving elements, i.e. how to understand the cause and effect relationships existing between them. The reading of the structure is done as follows: (i) continuous black arrows indicate a direct influence between the interrelated variables, that is, the greater the intensity of one variable, the greater the intensity of another; (ii) dotted arrows indicate an inverse influence, that is, the greater the intensity of a variable, the less the intensity of the variable related to it ${ }^{(34,35)}$.

As can be seen in Figure 2, it can be deduced that productivity is the main contributing factor for increasing competitiveness. Productivity is directly impacted by efficiency, technology, innovation and, also, by the ability of labors to quickly resolve problems that arise in organizations.

It should be noted that greater competitiveness positively impacts for a higher profit and market share. In addition, the greater the company competitiveness, the lower its risk of closing and more easily will be recognized as a sustainable company, both from the point of view of the shareholders and of the company itself. That the organization is recog- nized as sustainable contributes to an increase in its reputation, which may attract more investors. The fact of attracting investors ensures a greater investment capacity of that organization, which encourages investment in actions for operational improvements, positively impacting its effectiveness. Effectiveness, in turn, impacts productivity, which is the element that impacts competitiveness. In this way, a link occurs that reinforces the relationships of that structure, which contributes to the increase of the company competitiveness.

From the understanding of the systemic map, it is possible to have a greater awareness of the existing relationships between competitiveness and productivity, as well as the elements that impact on those two factors. From the understanding of the interrelationships of the elements pointed out by the literature and presented through the links, it is possible to identify the main elements that reinforce competitiveness in companies.

\section{Conclusion}

The systematic literature review confirms the direct relationship between productivity and com- 
petitiveness, as well as the link between the measure of production efficiency and productivity. It should be noted that from the identification of these elements and their relationships, it is possible for companies to define specific actions, even in their most operational actions, but with a significant impact on increasing their productivity and competitiveness. The use of systemic thinking was fundamental to offer the direction to interpret the relations between the drivers of competitiveness in a holistic way.

Finally, productivity stood out among other drivers of the company competitiveness, confirming its importance in determining competitiveness in itself. Future studies can be directed to the analysis of the other aspects identified in this study, as well as in its confirmation and the inclusion of more elements. We also suggest in the state of art of Systemic Thinking related to competitiveness and productivity. The limitations of this study consist of its theoretical nature, there is a need for a study that explores to verify in practice the drivers of competitiveness at the company level.

\section{References}

1. Cunha J. Folha de São Paulo. [site da Web]. Folha Uol: folha.uol.com.br; 2015.- [acesso em 20 de novembro de 2017] Available from: http:// www1.folha.uol.com.br/mercado/2015/09/ 1688175-brasil-cai-18-posicoes-em-ranking-de-competitividade.shtml

2. García SML. Una propuesta para la determinación de la competitividad en la pyme latinoamericana. Pensam y gestión. 2012; 6276:93-124.

3. Klaus S, Sala-i-Martin X, Brende B. The Global Competitiveness Report 2013 - 2014. Geneva: World Economic Forum Reports 2014.

4. Siudek T, Zawojska A. Competitiveness in the economic concepts, theories and empirical research. Acta Sci Pol. 2014;13(1):91-108.

5. Wright P, Kroll MJ, Parnell J. Administração estratégica: conceitos. $4^{\mathrm{a}}$ ed. São Paulo: Atlas; 2011.Buckley PJ, Pass CL, Prescott K.
Measures of International Competitiveness: A Critical Survey. Journal of Marketing Management. 1988; 4(2):175-200. DOI: 10.1080/0267257X.1988.9964068

6. Laureti T, Viviani A. Competitiveness and productivity: a case study of Italian firms. Appl Econ. 2011; 43(20):2615-25.

7. Montanari MG, Miranda RA de M, Giraldi JDME. Uma comparação quantitativa entre dois índices de competitividade. Glob Compet Governability. 2014; 8(2):121-36.

8. Hu W, Wall G. Environmental Management, Environmental Image and the Competitive Tourist Attraction. J Sustain Tour. 2005; 13(6):617-35.

9. Buckley PJ, Pass CL, Prescott K. Measures of international competitiveness: A critical survey. J Mark Manag. 1988;4(2):175-200.

10. Schwab K. The Global Competitiveness Report 2014-2015. Geneva: World Economic Forum Reports 2014.

11. Rojas MAM, Cerda GCP, García BL, Barcenas RAR. Innovation and competitiveness in SMEs: the local experience in San Luis Potosi, México. J Mark Manag. 2013; 4(1):74-92.

12. Wysokinska Z. Competitiveness and its relationships with productivity and sustainable development. Fibres Text East Eur. 2003;11(3):11-4.

13. Krugman PR, Obstfeld M. International economics: theory and policy. $3^{\mathrm{a}}$ ed. New York, New York, USA: Harper Collins; 1994.

14. Porter ME. The Competitive Advantage of Nations. $1^{a}$ ed. New York, New York, USA: Campus Elsevier; 1990.

15. Rathore A, Mohanty RP, Lyons AC, Barlow N. Performance management through strategic total productivity optimisation. Int $\mathrm{J} \mathrm{Adv}$ Manuf Technol. 2005; 25(9-10):1020-8.

16. Charnes A, Cooper WW, Rhodes E. Measuring the efficiency of decision making units. Eur J Oper Res. 1978; 2:429-44.

17. Eilon S. Framework for Profitability and Productivity Measures. Interfaces (Providence). 1985; 15(3):31-40. 
18. Ferreira LF, Torres MM. Contributo para a revisão da literatura sobre produtividade no Âmbito da economia empresarial. Rev. Bras. Gest. Negócios. 2005; 7:47-57.

19. Bornia AC. Análise Gerencial de Custos: Aplicação em Empresas Modernas. $1^{a}$ ed. Porto Alegre: Bookman; 2002.

20. Moreira DA. Medida da produtividade na empresa moderna. $1^{\text {a }}$ ed. São Paulo: Pioneira; 1991.

21. Allmon E, Haas CT, Borcherding JD, Goodrum PM. U.S. Construction Labor Productivity Trends, 1970-1998. J Constr Eng Manag. 2001; 126(2):97.

22. Bennett A, Hui J, Silver MS. A framework for productivity analysis at the organisational level: Method and an applied case. Eng Costs Prod Econ. 1987; 12(1-4):401-11. DOI 10.1016/0167-188X(87)90102-9

23. McLaughlin P. Measuring productivity. Manag Serv. 2014; 58(4):31-7.

24. Sabonienè A, Karazijienė Ž. Productivity Dynamics in Lithuanian Manufacturing Industry. Econ Manag. 2012; 17(2):560-7.

25. Contemp Account Res 2005, Issue 2 [site Web]. Toronto: 2005. [acesso em: 20 de novembro de 2017]. CALLEN JL, MOREL M, FADER C. Productivity Measurement and the Relationship between Plant Performance and JT Intensity. Available from: http://search. ebscohost.com/login.aspx?direct $=$ true $\& \mathrm{db}=$ bth\&AN=17434798\&lang=pt-br\&site=ehost-live

26. Usubamatov R, Ismail KA, Sah JM. Mathematical models for productivity and availability of automated lines. The International Journal of Advanced Manufacturing Technology 2013; 59-69.

27. Transp Res Part A [site Web] Elsevier: 1992. [acesso em: 20 de novembro de 2017]. Oum TH, Tretheway MW, Waters II WG. Concepts, methods and purposes of productivity measurement in transportation. Available from: http://www.scopus.com/inward/ record.url?eid=2-s2.0-0027040021\&part-
nerID $=40 \& \operatorname{md} 5=02 \mathrm{c} 64 \mathrm{~b} 15 \mathrm{be} 7 \mathrm{~d} 3 \mathrm{da} 3 \mathrm{f}-$ ec4d8f6d49322f1

28. Contador JL. Metodologia para a formulação da estratégia competitiva de manufatura : Um methodology for formulating the competitive strategy of manufacturing: A Quantitative Approach. 2011; 8(4):338-58.

29. Andrade AL, Seleme A, Rodrigues LH, Souto R. Pensamento Sistêmico: Caderno de campo: o desafio da mudança sustentada nas organizações e na sociedade. $1^{\mathrm{a}}$ ed. Porto Alegre: Bookman; 2006.

30. Andrade AL. O curso do pensamento sistêmico. $1^{a}$ ed. São Paulo: Digital Publish \& Print Editora; 2014.

31. Senge PM. A Quinta Disciplina: arte, teoria e prática da organização de aprendizagem. São Leopoldo: Best Seller; 2009.

32. Senge PM. The Fifth Discipline: The Art and Practice of the Learning Organization. $15^{\mathrm{a}} \mathrm{ed}$. New York: Currency Doubleday; 1990.

33. Morandi MIWM, Camargo LFR. Revisão sistemática da literatura. In: Design science research: método de pesquisa para avanço da ciência e tecnologia. Porto Alegre: Bookman; 2015. p. 141-75.

34. Boone J. A New Way to Measure Competition. Econ J. 2008; 118(531):1245-61. DOI: 10.1111/j.1468-0297.2008.02168.x

35. Rojas MAM, Cerda GCP, García BL, Barcenas RAR. Innovation and Competitiveness in SMEs : The Local Experience in San Luis Potosi. Int J Bus Soc Sci. 2013; 4(15):89-97.

36. Esser W. Hillebrand D. Messner J. Meyer-Stamer. Competitividad internacional de las empresas y politicas requeridas: Competitividad Sistémica. Berlin Instituto Alemán de Desarrollo. (1996)

37. Kitchenham B, Brereton P, Budgen D, Turner M. Bailey J, Linkman S. Systematic literature reviews in software engineering $-\mathrm{A}$ 
systematic literature review. Information and

Software Technology 51 (2009) 7-15.

38. Porter M. Competitive Advantage. New York, The Free Press, 1985
39. Shimizu, M.; Wainai, K.; Avedillo Cruz, E. Value added productivity measurement and its practical implications with linkage between productivity and profitability. Japan Productivity Center for Socio-Economic Development, Tokio, p. 10-12, Sep/Oct 1997.

Appendix 1

\begin{tabular}{|c|c|c|c|c|c|c|}
\hline BASE & \multicolumn{3}{|c|}{ COMBINAÇÃO } & \multirow{2}{*}{$\begin{array}{c}\text { GERAL } \\
\mathbf{5 8 8}\end{array}$} & \multirow{2}{*}{$\begin{array}{c}\text { CLASSIFICADOS TÍTULO } \\
\mathbf{2}\end{array}$} & BOOK \\
\hline \multirow{9}{*}{ EAsco } & PRODUCT * & MEASUR* & INDUSIR* & & & \multirow{3}{*}{$\mathbf{8}$} \\
\hline & PRODUCT ${ }^{*}$ & MEASUR* & MANUFACTUR* & 305 & 10 & \\
\hline & PRODUCT & MEASUR & OPERATIONS & 137 & 8 & \\
\hline & PRODUCT ${ }^{*}$ & PERFORMANCE & INDUSTR* & 389 & $\mathbf{8}$ & \multirow{3}{*}{3} \\
\hline & PRODUCT & PERFormance & MANUFACTUR* & 179 & $\mathbf{1 0}$ & \\
\hline & PRODUCT ${ }^{*}$ & PERFORMANCE & OPERATIONS & 89 & 7 & \\
\hline & PRODUCT ${ }^{*}$ & INDEX & INDUSIR* & 185 & $\mathbf{8}$ & \multirow{3}{*}{4} \\
\hline & PRODUCT & INDEX & MANUFACTUR* & 85 & 8 & \\
\hline & PRODUCT ${ }^{*}$ & INDEX & OPERATIONS & 31 & 4 & \\
\hline BASE & \multicolumn{3}{|c|}{ COMBINAÇÃO } & GERAL & CLASSIFICADOS TÍTULO & BOOK \\
\hline \multirow{9}{*}{ ScOPus } & PRODUCT & MEASUR* & INDUSIR* & 627 & 31 & \multirow{3}{*}{11} \\
\hline & PRODUCT ${ }^{*}$ & MEASUR ${ }^{*}$ & MANUFACTUR* & $\mathbf{2 8 7}$ & 16 & \\
\hline & PRODUCTI* & MEASUR* & OPERATION* & 245 & $\underline{7}$ & \\
\hline & PRODUCT ${ }^{*}$ & PERFORAMANCE & INDUSIR* & 824 & 16 & \multirow{3}{*}{3} \\
\hline & PRODUCT ${ }^{*}$ & PERFORMANCE & MANUFACTUR* & 453 & 12 & \\
\hline & PRODUCTI* & PERFORMANCE & OPEAATION* & 496 & 13 & \\
\hline & PRODUCT $*$ & INDEX & INDUSIR* & 377 & 7 & \multirow{3}{*}{2} \\
\hline & PRODUCT ${ }^{*}$ & INDEX & MANUFACTUR* & 116 & 6 & \\
\hline & PRODUCT $*$ & INDEX & OPEAATON* & 171 & 6 & \\
\hline BASE & \multicolumn{3}{|c|}{ COMBINAÇÃO } & GERAL & CLASSIFICADOS TíTULO & BOOK \\
\hline \multirow{9}{*}{ SCIBO } & PRODUT* & MBDIC̄ão & INDUSIR* & B & B & \multirow{3}{*}{ - } \\
\hline & PRODUI* & MBDIÇĀO & MANUFATURA & $\boldsymbol{B}$ & $\boldsymbol{B}$ & \\
\hline & PRODUI" & MBDIÇĀO & OPERAC & $\boldsymbol{\theta}$ & $\boldsymbol{\theta}$ & \\
\hline & ProDUI" $*$ & PERFORMANCE & INDUSIR* & B & B & \multirow{3}{*}{ B } \\
\hline & PRODUI" & PERFORMANCF & MANUFATURA & - & B & \\
\hline & PRODUI"* & PERFORAMANCE & OPEAC * & $\boldsymbol{B}$ & $\boldsymbol{\theta}$ & \\
\hline & PRODUI"* & ÍNDICE & INDUSIR* & - & - & \multirow{3}{*}{ B } \\
\hline & PRODUI $*$ & ÍNDICE & MANUFATURA & B & B & \\
\hline & PRODUT* & ÍNDICE & OPERAC* & 2 & $\boldsymbol{\theta}$ & \\
\hline
\end{tabular}

\begin{tabular}{|l|l|}
\hline P-001 & $\begin{array}{l}\text { SABONIENE, A; KARAZIJIENE, Ž. PRODUCTIVITY DYNAMICS IN LITHUANIAN MANU- } \\
\text { FACTURING INDUSTRY. Economics \& Management. 17, 2, 560-566, Apr. 2012. ISSN: } \\
18226515 .\end{array}$ \\
\hline P-002 & $\begin{array}{l}\text { ELDRIDGE, D. Measurement productivity - a key driver. Manufacturers' Monthly. 112, May } \\
\text { 2008. ISSN: 00252530. }\end{array}$ \\
\hline P-003 & $\begin{array}{l}\text { DIEWERT, WE. THE MEASUREMENT OF PRODUCTIVITY. Bulletin of Economic Research. } \\
44,3,163-198, \text { July 1992. ISSN: 03073378. }\end{array}$ \\
\hline
\end{tabular}




\begin{tabular}{|c|c|}
\hline P-004 & $\begin{array}{l}\text { CALLEN, JL; MOREL, M; FADER, C. Productivity Measurement and the Relationship be- } \\
\text { tween Plant Performance and JIT Intensity. Contemporary Accounting Research. 22, 2, } \\
\text { 271-309, 2005. ISSN: 08239150. }\end{array}$ \\
\hline P-005 & $\begin{array}{l}\text { Measuring a firm's productivity. BOFIT Discussion Papers. 26, 10-13, Oct. 2, } 2013 . \\
\text { ISSN: } 14564564 .\end{array}$ \\
\hline P-006 & $\begin{array}{l}\text { EILON, S. A Framework for Profitability and Productivity Measures. Interfaces. 15, 3, 31- } \\
\text { 40, May 1985. ISSN: } 00922102 \text {. }\end{array}$ \\
\hline P-007 & $\begin{array}{l}\text { GULLICKSON, W. Measurement of productivity growth in U.S. manufacturing. Monthly } \\
\text { Labor Review. 118, 7, 13, July 1995. ISSN: } 00981818\end{array}$ \\
\hline P-008 & $\begin{array}{l}\text { VAN ARK, B; TIMMER, M. INDUSTRY PRODUCTIVITY COMPARISONS. De Economist (0013- } \\
063 \mathrm{X}) .150,1,95-109, \text { Mar. 2002. ISSN: 0013063X. }\end{array}$ \\
\hline P-009 & $\begin{array}{l}\text { MCLAUGHLIN, P. Measuring productivity. (cover story). Management Services. 58, 4, 31- } \\
\text { 37, 2014. ISSN: } 03076768 .\end{array}$ \\
\hline $\mathrm{P}-010$ & $\begin{array}{l}\text { NEEF, A; KASK, C. Manufacturing productivity and labor costs in } 14 \text { economies. Monthly } \\
\text { Labor Review. } 114,12,24 \text {, Dec. } 1991 \text {. ISSN: } 00981818 .\end{array}$ \\
\hline P-011 & $\begin{array}{l}\text { HSIAO, F; PARK, C. Korean And Taiwanese Productivity Performance: Comparisons at } \\
\text { Matched Manufacturing Levels. Journal of Productivity Analysis. 23, 1, 85-107, Jan. } 2005 . \\
\text { ISSN: 0895562X. }\end{array}$ \\
\hline P-012 & $\begin{array}{l}\text { USUBAMATOV, R; ISMAIL, K; SAH, J. Mathematical models for productivity and availability } \\
\text { of automated lines. International Journal of Advanced Manufacturing Technology. 66, 1-4, } \\
\text { 59-69, Apr. 15, 2013. ISSN: } 02683768 \text {. }\end{array}$ \\
\hline P-013 & $\begin{array}{l}\text { DAVIS, AG. Forecast Modelling: A Practical Approach To Productivity Improvement. Indus- } \\
\text { trial Management. 30, 3, 14, May 1988. ISSN: } 00198471 .\end{array}$ \\
\hline P-014 & $\begin{array}{l}\text { R.N. Joshi S.P. Singh, (2010),"Estimation of total factor productivity in the Indian garment } \\
\text { industry", Journal of Fashion Marketing and Management: An International Journal, Vol. } \\
14 \text { Iss1 pp. } 145 \text { - } 160\end{array}$ \\
\hline P-015 & $\begin{array}{l}\text { FARIÑAS, JC; RUANO, S. The Dynamics of Productivity: A Decomposition Approach Us- } \\
\text { ing Distribution Functions. Small Business Economics. 22, 3/4, 237-251, Apr. } 2004 . \\
\text { ISSN: 0921898X. }\end{array}$ \\
\hline P-016 & $\begin{array}{l}\text { TRETHEWAY, MW; OUM, TH; WATERS, WG. Concepts, methods and purposes of produc- } \\
\text { tivity measurement in transportation. Transportation Research Part A: Policy \& Practice. } \\
\text { 26A, 6, 493, Nov. 1992. ISSN: 09658564. }\end{array}$ \\
\hline P-017 & $\begin{array}{l}\text { M.I. SHAHIDUL S.T. SYED SHAZALI, (2011),"Dynamics of manufacturing productivity: } \\
\text { lesson learnt from labor intensive industries", Journal of Manufacturing Technology Man- } \\
\text { agement, Vol. } 22 \text { Iss } 5 \text { pp. } 664-678 \text {. }\end{array}$ \\
\hline P-018 & $\begin{array}{l}\text { BENNETT, A.J. HUI; AND M.S. SILVER. A framework for productivity analysis at the or- } \\
\text { ganisational level: method and an applied case .Engineering Costs and Production Eco- } \\
\text { nomics, } 12 \text { (1987) 401-411 } 401 \text { Elsevier Science Publishers B.V., Amsterdam. }\end{array}$ \\
\hline P-019 & $\begin{array}{l}\text { BILLER, S; MEERKOV, SM; YAN, C. Raw material release rates to ensure desired produc- } \\
\text { tion lead time in Bernoulli serial lines. International Journal of Production Research. } 51 \text {, } \\
14,4349-4364 \text {, July 15, 2013. ISSN: } 00207543 \text {. }\end{array}$ \\
\hline
\end{tabular}




\begin{tabular}{|c|c|}
\hline P-020 & $\begin{array}{l}\text { CHOI, Y; HAHN, CH. Effects of Imported Intermediate Varieties on Plant Total Factor Pro- } \\
\text { ductivity and Product Switching: Evidence from Korean Manufacturing Effects of Imported } \\
\text { Intermediate Varieties on Plant Total Factor Productivity and Product Switching: Evidence } \\
\text { from.. Asian Economic Journal. 27, 2, 125-143, June 2013. ISSN: } 13513958\end{array}$ \\
\hline $\mathrm{P}-021$ & $\begin{array}{l}\text { CHINDA, T. A Dynamic Model of Productivity Enhancement in the Thai Food Industry. En- } \\
\text { gineering Management Journal. 24, 2,15-29, June 2012. ISSN: } 10429247\end{array}$ \\
\hline $\mathrm{P}-022$ & $\begin{array}{l}\text { RATHORE, A; et al. Performance management through strategic total productivity opti- } \\
\text { misation. International Journal of Advanced Manufacturing Technology. } 25,9 / 10,1020- \\
\text { 1028, May 2005. ISSN: } 02683768 \text {. }\end{array}$ \\
\hline P-023 & $\begin{array}{l}\text { O'DONNELL, C. An aggregate quantity framework for measuring and decomposing produc- } \\
\text { tivity change. Journal of Productivity Analysis. 38, 3, 255-272, Dec. 2012. ISSN: 0895562X. }\end{array}$ \\
\hline P-024 & $\begin{array}{l}\text { CORRADO, C; GILBERT, C. Industrial production and capacity utilization.. Federal Reserve } \\
\text { Bulletin. 83, 2,67, Feb. 1997. ISSN: } 00149209 .\end{array}$ \\
\hline P-025 & $\begin{array}{l}\text { EKER, M; PALA, F. The Effect of Competition, Just In Time Production and Total Quality } \\
\text { Management on the Use of Multiple Performance Measures: An Empirical Study. Journal } \\
\text { of Economic \& Social Research. 10, 1, 35-72, Jan. 2008. ISSN: } 13021060\end{array}$ \\
\hline P-026 & $\begin{array}{l}\text { DINIS-CARVALHO, J; ALVES, AC; SOUSA, RM. Moving from job-shop to production cells } \\
\text { without losing flexibility: a case study from the wooden frames industry. South African } \\
\text { Journal of Industrial Engineering. 25, 3, 212-225, Nov. 2014. ISSN: } 1012277 \text { X. }\end{array}$ \\
\hline P-027 & $\begin{array}{l}\text { PICO, JF; MARTÍNEZ, HC. Efficiency and productivity in venezuelan industry direct reduc- } \\
\text { tion iron in guayana region. (english). : eficiencia y productividad en la industria vene- } \\
\text { zolana de hierro de reducción directa. (Spanish). Revista Negotium. } 9,25,86-114 \text {, July } \\
\text { 2013. ISSN: } 18561810 \text {. }\end{array}$ \\
\hline P-028 & $\begin{array}{l}\text { AMIRTEIMOORI, A; KORDROSTAMI, S. Production planning: a DEA-based approach. In- } \\
\text { ternational Journal of Advanced Manufacturing Technology. 56, 1-4, 369-376, Sept. } 2011 . \\
\text { ISSN: } 02683768\end{array}$ \\
\hline P-029 & $\begin{array}{l}\text { FERREIRA LF, TORRES MM. Contributo para a revisão da literatura sobre produtividade no } \\
\text { Âmbito da economia empresarial. Rev. Bras. Gest. Negócios. 2005; 7:47-57. }\end{array}$ \\
\hline P-030 & $\begin{array}{l}\text { SCOTT E. ATKINSON, PAUL W. WILSON. Comparing mean efficiency and productivity } \\
\text { scores from small samples: A bootstrap methodology. Journal of Productivity AnalysisJuly } \\
\text { 1995, Volume 6, Issue 2, pp 137-152 }\end{array}$ \\
\hline P-031 & $\begin{array}{l}\text { PATRIZIA GARENGO, GIOVANNI BERNARDI. Organizational capability in SMEs: Perfor- } \\
\text { mance measurement as a key system in supporting company development. International } \\
\text { Journal of Productivity and Performance Management, } 2007 \text {, Vol. } 56 \text { Iss: } 5 / 6 \text {, pp. } 518-532 \text {. }\end{array}$ \\
\hline
\end{tabular}

\begin{tabular}{|c|c|c|c|c|c|c|}
\hline BASE & \multicolumn{3}{|c|}{ COMBINAÇÃO } & GERAL & CLASSIFICADOS TÍTULO & BOOK \\
\hline \multirow{9}{*}{ EBSCO } & COMPETITI* & MEASURE* & INDUSTR* & 499 & 24 & 10 \\
\hline & COMPETITI* & MEASURE* & MANUFACTUR* & 149 & 15 & 4 \\
\hline & COMPETITI* & MEASURE* & OPERATION* & 182 & 6 & 1 \\
\hline & COMPETITI* & PERFORMANCE & INDUSTR* & 864 & 37 & 4 \\
\hline & COMPETITI* & PERFORMANCE & MANUFACTUR* & 168 & 11 & 4 \\
\hline & COMPETITI* & PERFORMANCE & OPERATION* & 137 & 0 & 0 \\
\hline & COMPETITI* & INDEX & INDUSTR* & 108 & 23 & 2 \\
\hline & COMPETITI* & INDEX & MANUFACTUR* & 22 & 1 & 1 \\
\hline & COMPETITI* & INDEX & OPERATION* & 23 & 0 & 0 \\
\hline
\end{tabular}




\begin{tabular}{|c|c|c|c|c|c|c|}
\hline BASE & \multicolumn{3}{|c|}{ COMBINAÇÃO } & GERAL & CLASSIFICADOS TÍTULO & BOOK \\
\hline \multirow{5}{*}{ SCOPUS } & COMPETITI* & MEASURE* & INDUSTR* & 466 & 7 & 0 \\
\hline & COMPETITI* & MEASURE* & OPERATION* & 113 & $\begin{array}{c}0 \\
0\end{array}$ & 0 \\
\hline & COMPETITI* & PERFORMANCE & MANUFACTUR* & 348 & 0 & 0 \\
\hline & COMPETITI* & PERFORMANCE & OPERATION ${ }^{*}$ & 62 & 1 & 0 \\
\hline & COMPETITI* & INDEX & INDUSTR* & 185 & 0 & 0 \\
\hline BASE & \multicolumn{3}{|c|}{ COMBINAÇÃO } & GERAL & CLASSIFICADOS TÍTULO & BOOK \\
\hline \multirow{4}{*}{ SCIELO } & COMPETITI* & MEDICZĀO & INDUSTR* & 0 & o & 0 \\
\hline & COMPETITI* & MEDIÇĀO & MANUFATURA & 0 & 0 & 0 \\
\hline & COMPETITI* & MEDIÇÃO & OPERAC* & 0 & 0 & 0 \\
\hline & COMPETITI* & PERFORMANCE & INDUSTR* & 0 & 0 & 0 \\
\hline
\end{tabular}

\begin{tabular}{|c|c|}
\hline $\mathrm{CO}-001$ & $\begin{array}{l}\text { BUCKLEY, PJ; PASS, CL; PRESCOTT, K. Measures of International Competi- } \\
\text { tiveness: Empirical Findings from British Manufacturing Companies. Journal of } \\
\text { Marketing Management. 6, 1, 1-13, 1990. ISSN: } 0267257 \mathrm{X} \text {. }\end{array}$ \\
\hline $\mathrm{CO}-002$ & $\begin{array}{l}\text { BUCKLEY, PJ; PASS, CL; PRESCOTT, K. Measures of International Competi- } \\
\text { tiveness: A Critical Survey. Journal of Marketing Management. 4, 2, 175-200, } 1988 . \\
\text { ISSN: 0267257X. }\end{array}$ \\
\hline CO-003 & $\begin{array}{l}\text { NICOLE E. COVIELLO, PERVEZ N.;GHAURI, KRISTINA A-M. MARTIN; in- } \\
\text { ternational competitiveness: empirical findings from sme service eirms; Journal of } \\
\text { International Marketing Vol. 6. No. 2. 1998. p. 4,ISSN 1069-03IX. }\end{array}$ \\
\hline CO-004 & $\begin{array}{l}\text { HARDWICK, P; Wen, D. The Competitiveness of EU Insurance Industries. Service } \\
\text { Industries Journal. 18, 1, 39-53, Jan. 1998. ISSN: } 02642069 .\end{array}$ \\
\hline $\mathrm{CO}-005$ & $\begin{array}{l}\text { HITCHENS, D; et al. Competitiveness, Environmental Performance and Ma- } \\
\text { nagement of SMEs. Greener Management International. 44, 45-57, 2003. ISSN: } \\
09669671 \text {. }\end{array}$ \\
\hline CO-006 & $\begin{array}{l}\text { MONTANARI, MG; DE MATOS MIRANDA, RA; ENGRACIA GIRALDI, JM. } \\
\text { Uma comparação quantitativa entre dois } 121 \text { índices de competitividade. (Portugue- } \\
\text { se). : A quantitative comparison of two competitiveness indexes. (English). GCG: } \\
\text { Revista de Globalización, Competitividad \& Gobernabilidad. 8, 2, 121-136, May } \\
\text { 2014. ISSN: } 19887116 \text {. }\end{array}$ \\
\hline CO-007 & $\begin{array}{l}\text { SIUDEK, T; ZAWOJSKA, A. Competitiveness in the economic concepts, theories } \\
\text { and empirical research. : koncepcje i teorie ekonomiczne oraz badania empiryczne } \\
\text { pojecia konkurencyjnosci. Acta Scientiarum Polonorum. Oeconomia. 91-108, Mar. } \\
\text { 2014. ISSN: } 16440757 \text {. }\end{array}$ \\
\hline CO-008 & $\begin{array}{l}\text { KABAK, Ö; et al. Cumulative belief degrees approach for analyzing the competi- } \\
\text { tiveness of the automotive industry. Knowledge-Based Systems. 70, 15-25, Nov. } \\
\text { 2014. ISSN: } 09507051\end{array}$ \\
\hline
\end{tabular}




\begin{tabular}{|c|c|}
\hline CO-009 & $\begin{array}{l}\text { NES, JS; LINDERMAN, K. Process management, innovation and efficiency per- } \\
\text { rmanceThe moderating effect of competitive intensity. Business Process Manage- } \\
\text { ent Journal. 20, 2, 335-358, Mar. 2014. ISSN: } 14637154 \text {. }\end{array}$ \\
\hline 0 & $\begin{array}{l}\text { rom a Large Multiproduct U.S. Firm. The Academy of Management Journal, 36, } \\
6,1652-1669 \text {, Dec.1993. }\end{array}$ \\
\hline 11 & $\begin{array}{l}\text { WACKER, JG; SHEU, C. Effectiveness of manufacturing planning and control sys- } \\
\text { tems on manufacturing competitiveness: evidence from global manufacturing data. } \\
\text { International Journal of Production Research. 44, 5, 1015-1036, Mar. 2006. ISSN: } \\
00207543\end{array}$ \\
\hline $\mathrm{O}-012$ & $\begin{array}{l}\text { BOONE, J. A New Way to Measure Competition. Economic Journal. 118, 531, } \\
\text { 1245-1261, Aug. 2008. ISSN: 00130133. }\end{array}$ \\
\hline 3 & $\begin{array}{l}\text { EKER, M; PALA, F. The Effect of Competition, Just In Time Production and Total } \\
\text { Quality Management on the Use of Multiple Performance Measures: An Empiri- } \\
\text { cal Study. Journal of Economic \& Social Research. 10, 1, 35-72, Jan. 2008. ISSN: } \\
13021060 \text {. }\end{array}$ \\
\hline $\mathrm{CO}-\mathrm{C}$ & $\begin{array}{l}\text { YBAKOVAS, E. Com } \\
\& \text { Management. } 912\end{array}$ \\
\hline 5 & $\begin{array}{l}\text { AHUMADA, VC. Competitividad internacional, productividad y costos laborales } \\
\text { unitarios en la industria manufacturera. (Spanish). : International Competitiveness, } \\
\text { Productivity and Unit Labor Costs in the Manufacturing Industry. (English). Fron- } \\
\text { tera Norte. } 22,44,7-39 \text {, July 2010. ISSN: } 01877372 \text {. }\end{array}$ \\
\hline 6 & $\begin{array}{l}\text { IURETI, T; VIVIANI, } \\
\text { n firms. Applied Econo }\end{array}$ \\
\hline $\mathrm{CO}-\mathrm{C}$ & $\begin{array}{l}\text { LUCATO, WC; et al. Model to measure the degree of competitiveness for auto par- } \\
\text { ts manufacturing companies. International Journal of Production Research. 50, 19, } \\
5508-5522 \text {, Oct. } 2012 \text {. ISSN: } 00207543 \text {. }\end{array}$ \\
\hline O-018 & $\begin{array}{l}\text { HUSAVAT, K; HAAPASALO, H; LIN, B. Achieving enterprise competitiveness } \\
\text { through an effective management process. Human Systems Management. 30, 3, } \\
\text { 115-124, June 2011. ISSN: } 01672533 \text {. }\end{array}$ \\
\hline CO-019 & $\begin{array}{l}\text { FISCHER, C; SCHORNBERG, S. Assessing the competitiveness situation of EU } \\
\text { food and drink manufacturing industries: An index-based approach. Agribusiness. } \\
23,4,473-495 \text {, Oct. } 2007 \text {. ISSN: } 07424477 \text {. }\end{array}$ \\
\hline CO-020 & $\begin{array}{l}\text { BAILY, MN; GERSBACH, H. Efficiency in Manufacturing and the Need for Glo- } \\
\text { bal Competition. Brookings Papers on Economic Activity. 307-358, 1995. ISSN: } \\
00072303 \text {. }\end{array}$ \\
\hline $\mathrm{CO}-021$ & $\begin{array}{l}\text { MARTÍNEZ ROJAS, MA; et al. Innovation and Competitiveness in SMEs: The Lo- } \\
\text { cal Experience in San Luis Potosi, Mexico. Journal of Marketing \& Management. 4, } \\
\text { 1, 74-92, May 2013. ISSN: } 21539715 .\end{array}$ \\
\hline
\end{tabular}




\begin{tabular}{|l|l|}
\hline CO-022 & $\begin{array}{l}\text { SAAVEDRA GARCÍA, ML. Una propuesta para la determinación de la competiti- } \\
\text { vidad en la pyme latinoamericana. (Spanish). Pensamiento \& Gestión. 33, 93-124, } \\
\text { July 2012. ISSN: 16576276. }\end{array}$ \\
\hline CO-023 & $\begin{array}{l}\text { DEGER, Ç; TÜRKCAN, B; KUMRAL, N. Competitive industrial performance in- } \\
\text { dex and its drivers: a comparative analysis on turkey and selected countries. Ege } \\
\text { Academic Review. 9, 4, 1375-1398, Oct. 2009. ISSN: 1303099X. }\end{array}$ \\
\hline CO-024 & $\begin{array}{l}\text { MARQUES, CS; FERREIRA, J. SME Innovative Capacity, Competitive Advantage } \\
\text { and Performance in a 'Traditional' Industrial Region of Portugal. (Spanish). Journal } \\
\text { of Technology Management \& Innovation. 4, 4, 53-68, Dec. 2009. ISSN: 07182724. }\end{array}$ \\
\hline CO-025 & $\begin{array}{l}\text { ISMAIL, AI; et al. The relationship between organisational competitive advantage } \\
\text { and performance moderated by the age and size of firms. Asian Academy of Mana- } \\
\text { gement Journal. 15, 2, 157-173, July 2010. ISSN: 13942603. }\end{array}$ \\
\hline CO-026 & $\begin{array}{l}\text { CONTADOR, J. Metodologia para a formulação da estratégia competitiva de ma- } \\
\text { nufatura: um enfoque quantitativo. (portuguese). : methodology for formulating the } \\
\text { competitive strategy of manufacturing: a quantitative approach. (English). Base. 8, } \\
\text { 4, 338-358, Oct. 2011. ISSN: 1807054X. }\end{array}$ \\
\hline CO-027 & $\begin{array}{l}\text { CHIANG, K; SHIANG-TAI, L. Competitiveness of manufacturing firms: an appli- } \\
\text { cation of fuzzy weighted average. IEEE Transactions on Systems, Man \& Cyberne- } \\
\text { tics: Part A. 29, 6, 661-667, Nov. 1999. ISSN: 10834427. }\end{array}$ \\
\hline
\end{tabular}
Commons Reconocimiento - Debe reconocer adecuadamente la autoría, proporcionar un enlace a la licencia e indicar si se han realizado cambios. Puede hacerlo de cualquier manera razonable, pero no de una manera que sugiera que tiene el apoyo del licenciador o lo recibe por el uso que hace. 
